\title{
Weed-Competitive Ability of Forage Maize Cultivars against Barnyardgrass
}

\author{
Khawar Jabran 1,2,a,* \\ ${ }^{I}$ Department of Plant Production and Technologies, Faculty of Agricultural Sciences and Technologies, Niğde Ömer Halisdemir University, \\ 51240 Niğde, Turkey \\ ${ }^{2}$ Department of Plant Protection, Faculty of Agriculture and Natural Sciences, Düzce University, 81620 Düzce, Turkey
}

${ }^{*}$ Corresponding author

\begin{tabular}{l|l}
\hline A R T I C LE IN F O & A B S T R A C T \\
\hline & Weed-competitive cultivars are desired in the wake of growing popularity of organic farming,
\end{tabular}

Research Article environmental pollution and evolution of herbicide resistance in weeds. This research work evaluated the weed competitive ability of three forage maize cultivars (ADA-523, AGA and SASA5) against the noxious weed barnyardgrass (Echinochloa crus-galli (L.) P.Beauv.). The study was conducted in spring 2018 and repeated in summer 2018. Results of this study showed that maizebarnyardgrass competition significantly decreased the growth of forage maize plants. For instance, barnyardgrass decreased the maize plant height by $11.9-16.9 \%$, leaf length by $13.3-20.2 \%$, leaf width by $20.2-27.4 \%$, and number of leaves by $14.3-25.0 \%$. Fresh and dry weights of maize plants were also significantly decreased as a result of weed-crop competition. Barnyardgrass decreased the shoot Keywords: Maize

Weed fresh weight (30.7-60.6\%), shoot dry weight (33.3-52.2\%), leaf fresh weight (33.4-56.5\%) and leaf dry weight (31.9-50.0\%) of the maize plants. An interactive effect of weed $\times$ maize cultivars was found non-significant. Forage maize cultivars also varied occasionally for their traits. Nevertheless, ADA-523 had a higher plant height, leaf length, leaf width, leaf fresh weight and leaf dry weight than the cultivars AGA and SASA-5. On the other hand, the cultivar SASA-5 had a higher shoot fresh weight, shoot dry weight and root fresh weight than the other cultivars in the study. This research work concluded that the forage maize cultivars in the study did not vary for the weedcompetitive ability. Further, barnyardgrass-maize competition could decrease the growth and development of the maize cultivars.

\section{Introduction}

Maize (Zea mays L.) is a multipurpose and important crop globally. This crop takes place among the three most important cereals in the world. Globally, the maize is grown on area of $187.9 \mathrm{~m}$ ha and produces more than 1060 $\mathrm{m}$ tons of grains (FAO, 2016). The major maize growing continents are Americas (53\%), Asia (29\%), Europe (11\%) and Africa $(7 \%)$, and a little less than one-third of the global caloric requirements are fulfilled by maize (Shiferaw et al., 2011; FAO, 2016). Important products and uses of maize may be summarized as animal feed, biofuels, flour, bread, starch, syrup, oil, chemicals (e.g., levulinic acid), forage and others (Jabran et al., 2007).

Sustainable maize production is desired in order to maintain the global food security. However, maize production in constrained by several factors, important of which include drought, chilling, poor soil fertility, climate change (abiotic stresses), and insect pests, diseases and weed infestations (biotic stresses) (Shiferaw et al., 2011). According to Oerke (2006), weeds could cause nearly $40 \%$ decreases in the global maize productivity. Echinchloa species (barnyardgrass and $E$. colona (L.) Link), Convolvulus arvensis L., Xanthium strumarium L., Amaranthus retrofl exus L., Digitaria sanguinalis (L.) Scop., Sorghum halepense (L.) Pers., Portulaca oleracea L., Chenopodium album L., and Cyperus spp. are important among the weeds that heavily infest the maize fields (Jabran et al., 2017).

Barnyardgrass takes place among the global weeds and infests several crops in many parts of the world (Bajwa et al., 2015). The weed has a great adaptability to diverse environmental conditions, possesses a capacity to produce 
high number of seeds (2000 to 4000 per plant), and has a strong competitive ability against crop plants (Bajwa et al., 2015). More than 30,000 seeds may be produced from barnyardgrass plants in $1 \mathrm{~m}^{2}$ (Bosnic and Swanton, 1997). Barnyardgrass infests several (particularly summer) crops and causes a significant decrease in growth and productivity of the infested crop. For example, this weed could decrease the maize leaf area by $\sim 22 \%$ and the grain yield by 24-35\% (Bosnic and Swanton, 1997; Travlos et al. 2011).

Recently, the concepts of organic agriculture and growing of crops without application of synthetic pesticides is gaining popularity (Crowder et al., 2010; Reganold and Wachter, 2016). This is because people are more conscious about their food and reluctant to consume the foodstuff that may have residues of pesticides. This fact leads to a restraint in the use of herbicides and other pesticides. Another important development is the evolution of herbicide resistance in weeds, which has intensely damaged the sustainability of weed control achieved through application of herbicides (Heap, 2014). The circumstances solicit for weed control methods that leave no pesticide residues in the food, and are be capable of suppressing the herbicide resistant weeds (Jabran and Chauhan, 2018a, b).

Crop-weed interference usually occurs throughout the period these grow together, and this interference will either be allelopathy or competition. Crop plants usually express their competitive ability against weeds by producing high biomass, plant height, leaf area, and absorbing high quantities of nutrients and moisture (Sardana et al., 2017). Usually, the information on the weed-competitive ability of the forage maize cultivars is scarce in the literature. Hence, this research work was conducted in order to determine the weed-competitive ability of three forage maize cultivars.

\section{Materials and Methods}

\section{Study Site and Seed Materials}

The study was conducted during spring and repeated in the summer 2018 in the research area of Faculty of Agriculture and Natural Science, Duzce University, Duzce, Turkey. Soil mixture was prepared by mixing soil $(50 \%)$, compost $(25 \%)$, and perlite $(25 \%)$. This mixture was analyzed for its physical and chemical characteristics and the results have been presented in the Table 1 .

Seeds of barnyardgrass were collected from the maize fields located in the Maize Research Institute, Sakarya; the weed seeds were then stored in a fridge at $4^{\circ} \mathrm{C}$ until these were used in the experiment. Similarly, seeds of three maize cultivars were obtained from the same research institute and tested for their germination. All the cultivars had a germination rate higher than $97 \%$.

\section{Treatments}

The research work included a weed-competition of maize cultivars with barnyardgrass weed. The cultivars were grown both as sole crop and in-competition with the weed. The maize cultivars were grown in pots that were 60 $\mathrm{cm}$ in height and $30 \mathrm{~cm}$ diameter. Each pot was filled with $3 \mathrm{~kg}$ soil mixture and sown with two seeds of maize. After the germination, each pot was maintained with a single maize plant. The plants in weedy treatments were additionally sown with ten barnyardgrass seeds and after germination the barnyardgrass number was maintained to six. The experiment had four replications and was arranged according to randomized complete block design.

\section{Data Recorded}

Data recording was done during termination of the experiment i.e., 7-8 weeks after sowing. Plant height of the maize plants (both in weedy and weed-free treatments) recorded with help of a meter rod. The heights was recorded starting from the ground surface to the highest point in each plant. Leaf length (average of the three longest leaves) and width were recorded using a meter rod. Number of leaves was counted manually for each plant. Plants were harvested close to the soil surface and weighed on an electric balance to record fresh weight. Further, the plants were separated into leaves and shoots, and fresh weights of leaves and shoots were recorded afterwards. These plant parts were then dried in the oven at $70^{\circ} \mathrm{C}$ until these had a constant weight; dry weights of these were recorded afterwards using an electric balance. Moreover, soil was removed from roots of the plants to record root fresh weight; the roots from each plant were dried in oven to record root dry weight. The weeds in the weedy treatment were harvested to record weed fresh weight; the weeds were then dried in the oven to record their dry weights.

\section{Statistical Analysis}

Data recorded were subjected to analysis of variance (ANOVA) using statistical software Statistix 8.0. Seasons (spring and summer), weed conditions and forage maize cultivars were considered as factors in the ANOVA. The means were separated from each other according to least significant difference (LSD) test at a probability level of 0.05 .

Table 1. Soil analysis for the soil used in the experiments

\begin{tabular}{l|c}
\multicolumn{1}{c|}{ Soil characteristics } & Value \\
\hline $\mathrm{pH}$ & 7.73 \\
$\mathrm{EC} 25 \mathrm{SS} / \mathrm{cm}$ & 0.49 \\
Texture & Loamy \\
Organic matter $(\%)$ & 3.7 \\
Nitrogen $(\%)$ & 0.18 \\
Available phosphorus $(\mathrm{mg} / \mathrm{kg})$ & 62.0 \\
Potassium $(\mathrm{mg} / \mathrm{kg})$ & 192.0 \\
Iron $(\mathrm{mg} / \mathrm{kg})$ & 3.0 \\
Zinc $(\mathrm{mg} / \mathrm{kg})$ & 0.3 \\
\hline
\end{tabular}


Table 2. Effect of weed-conditions and cultivars on different growth parameters of forage maize

\begin{tabular}{|c|c|c|c|c|c|c|c|c|}
\hline & \multicolumn{2}{|c|}{$\begin{array}{l}\text { Plant height } \\
\text { (cm) }\end{array}$} & \multicolumn{2}{|c|}{$\begin{array}{l}\text { Leaf length } \\
\text { (cm) }\end{array}$} & \multicolumn{2}{|c|}{$\begin{array}{l}\text { Leaf width } \\
\text { (cm) }\end{array}$} & \multicolumn{2}{|c|}{$\begin{array}{c}\text { Number of leaves } \\
\text { per plant }\end{array}$} \\
\hline & Spring & Summer & Spring & Summer & Spring & Summer & Spring & Summer \\
\hline \multicolumn{9}{|c|}{ Weed conditions } \\
\hline Weed-free & $70.9 \mathrm{~A}^{1}$ & $56.5 \mathrm{~A}$ & $51.2 \mathrm{~A}$ & $46.1 \mathrm{~A}$ & $3.62 \mathrm{~A}$ & $4.12 \mathrm{~A}$ & $7.0 \mathrm{~A}$ & $8.0 \mathrm{~A}$ \\
\hline Weedy & $62.4 \mathrm{~B}(11.9)^{2}$ & $46.9 \mathrm{~B}(16.9)$ & $44.4 \mathrm{~B}(13.3)$ & $36.8 \mathrm{~B}(20.2)$ & $2.89 \mathrm{~B}(20.2)$ & $2.99 \mathrm{~B}(27.4)$ & $6.0 \mathrm{~B}(14.3)$ & $6.0 \mathrm{~B}(25.0)$ \\
\hline LSD & 6.2 & 7.5 & 7.6 & 3.92 & 0.43 & 0.25 & 0.66 & 0.69 \\
\hline \multicolumn{9}{|c|}{ Maize cultivars } \\
\hline ADA-523 & 67.8 & $57.3 \mathrm{~A}$ & 48.4 & $45.7 \mathrm{~A}$ & $3.52 \mathrm{~A}$ & $3.92 \mathrm{~A}$ & 6.25 & 7.12 \\
\hline AGA & 63.5 & $45.3 \mathrm{~B}$ & 45.5 & $39.5 \mathrm{~B}$ & $2.76 \mathrm{~B}$ & $3.31 \mathrm{~B}$ & 6.75 & 7.25 \\
\hline SASA-5 & 68.8 & $52.4 \mathrm{AB}$ & 49.5 & $39.2 \mathrm{~B}$ & $3.50 \mathrm{~B}$ & $3.42 \mathrm{~B}$ & 6.50 & 6.87 \\
\hline LSD & NS & 9.2 & NS & 4.8 & 0.53 & 0.31 & NS & NS \\
\hline
\end{tabular}

$\mathrm{NS}=$ non-significant ${ }^{2}$ The means not sharing a letter in common in each row (for either the Weed conditions, or Maize cultivars) differ significantly at $\mathrm{p}=0.05$ according to least significant difference (LSD) test; ${ }^{2}$ The figures in the parenthesis show the percent decrease in the plant parameters due to competition with barnyardgrass.

Table 3. Effect of weed-conditions and cultivars on different growth parameters of forage maize

\begin{tabular}{|c|c|c|c|c|c|c|c|c|}
\hline & \multicolumn{2}{|c|}{$\begin{array}{l}\text { Shoot fresh weight } \\
(\mathrm{g} / \text { plant })\end{array}$} & \multicolumn{2}{|c|}{$\begin{array}{c}\text { Shoot dry weight } \\
\text { (g/plant) }\end{array}$} & \multicolumn{2}{|c|}{$\begin{array}{l}\text { Leaf fresh weight } \\
\text { (g/plant) }\end{array}$} & \multicolumn{2}{|c|}{$\begin{array}{l}\text { Leaf dry weight } \\
\text { (g/plant) }\end{array}$} \\
\hline & Spring & Summer & Spring & Summer & Spring & Summer & Spring & Summer \\
\hline \multicolumn{9}{|c|}{ Weed conditions } \\
\hline Weed-free & $16.6 \mathrm{~A}^{1}$ & $14.2 \mathrm{~A}$ & $2.7 \mathrm{~A}$ & $2.3 \mathrm{~A}$ & $2.56 \mathrm{~A}$ & $2.3 \mathrm{~A}$ & $0.47 \mathrm{~A}$ & $0.48 \mathrm{~A}$ \\
\hline Weedy & $11.5 \mathrm{~B}(30.7)^{2}$ & $5.6 \mathrm{~B}(60.6)$ & $1.8 \mathrm{~B}(33.3)$ & $1.1 \mathrm{~B}(52.2)$ & $1.7 \mathrm{~B}(33.4)$ & $1.0 \mathrm{~B}(56.5)$ & $0.32 \mathrm{~B}(31.9)$ & $0.24 \mathrm{~B}(50.0)$ \\
\hline LSD & 3.99 & 2.9 & 0.71 & 0.56 & 0.63 & 0.46 & 1.34 & 0.09 \\
\hline \multicolumn{9}{|c|}{ Maize cultivars } \\
\hline ADA-523 & $12.2 \mathrm{~B}$ & 11.7 & $1.8 \mathrm{~B}$ & 1.95 & 1.98 & $1.98 \mathrm{~A}$ & 0.34 & $0.44 \mathrm{~A}$ \\
\hline AGA & $12.5 \mathrm{~B}$ & 9.4 & $1.9 \mathrm{~B}$ & 1.65 & 1.91 & $1.48 \mathrm{~B}$ & 0.34 & $0.32 \mathrm{~B}$ \\
\hline SASA-5 & $17.4 \mathrm{~A}$ & 8.7 & $3.0 \mathrm{~A}$ & 1.48 & 2.51 & $1.45 \mathrm{~B}$ & 0.50 & $0.32 \mathrm{~B}$ \\
\hline LSD & 4.9 & NS & 0.87 & NS & NS & 0.46 & NS & 0.11 \\
\hline
\end{tabular}

NS = non-significant; The means not sharing a letter in common in each row (for either the Weed conditions, or Maize cultivars) differ significantly at $\mathrm{p}=0.05$ according to least significant difference (LSD) test; ${ }^{2}$ The figures in the parenthesis show the percent decrease in the plant parameters due to competition with barnyardgrass.

\section{Results}

Effect of season as a factor was found significant as a result of the analysis of variance, hence, results are presented separately for the summer and spring season. Moreover, analysis of variance also indicated that weed conditions and cultivars did not have a significant interaction; hence, data only for the main factors (i.e., weed conditions, forage maize cultivars) have been presented.

A comparison of weedy and weed-free treatments showed that barnyardgrass-maize competition led to a decrease in the growth parameters of forage maize (Table 2). Weedy conditions (barnyardgrass-maize competition) decreased the plant height (11.9-16.9\%), leaf length (13.3$20.2 \%$ ), leaf width (20.2-27.4\%), and number of leaves of forage maize cultivars. Maize cultivars had statistically similar plant height and leaf length when sown in spring but a statistically different plant height and leaf length when sown in the summer season (Table 2). In the summer season, cultivar ADA-523 had a higher plant height and leaf length than the AGA and SASA-5 cultivars. Similarly, both for the spring and summer seasons, ADA-523 had a higher leaf width than the AGA and SASA-5 cultivars. The three cultivars had a statistically similar number of leaves both during the spring and summer season plantations.

Barnyardgrass-maize competition decreased the maize shoot fresh weight (30.7-60.6\%), maize shoot dry weight (33.3-52.2\%), leaf fresh weight (33.4-56.5\%), and leaf dry

weight (31.9-50.0\%) during spring and summer seasons (Table 3). SASA-5 had higher fresh weight and dry weight than the other two cultivars in the spring season but in the summer season, all the cultivars had statistically similar fresh and dry weights (Table 3). ADA-523 had a higher leaf fresh weight and leaf dry weight than the other two cultivars in the study during the summer season but in the spring, all the cultivars had a statistically similar leaf fresh weight and leaf dry weight.

Weed-competition decreased the root fresh and dry weights in both the seasons (Table 4). Barnyardgrassmaize competition decreased the fresh weight of maize roots by 49.7 to $56.9 \%$ and the dry weight by 39.1 to $53.5 \%$. In the spring season, ADA-523 had the lowest root fresh weight while in the summer season, all the cultivars had a statistically similar root fresh weight (Table 4). Moreover, the highest root dry weight was noted for SASA-5 in the spring season while in the summer season, AGA cultivar had the highest root dry weight. Barnyardgrass fresh weight in spring was similar for all the cultivars but in the summer season, ADA-523 caused a higher suppression of barnyardgrass that the other two cultivars (Table 5). Forage maize cultivars did not differ for their suppression of barnyardgrass dry weight in either of the seasons (i.e. spring or summer). 
Table 4. Effect of weed-conditions and cultivars on different root biomass of forage maize

\begin{tabular}{l|cccc}
\hline \multirow{2}{*}{} & \multicolumn{2}{c}{ Root fresh weight $(\mathrm{g})$} & \multicolumn{2}{c}{ Root dry weight $(\mathrm{g})$} \\
\cline { 2 - 5 } & \multicolumn{5}{c}{ Spring } & Summer & Spring \\
\hline Weed-free & $31.6 \mathrm{~A}^{1}$ & $17.7 \mathrm{~A}$ & $6.4 \mathrm{~A}$ \\
Weedy & $13.6 \mathrm{~B}(56.9)^{2}$ & $8.9 \mathrm{~B}(49.7)$ & $11.4 \mathrm{~A}$ & $3.9 \mathrm{~B}(39.1)$ \\
LSD & 10.4 & 3.09 & $5.3 \mathrm{~B}(53.5)$ & 0.98 \\
\hline \multicolumn{5}{c}{ Maize cultivars } \\
\hline ADA-523 & $10.4 \mathrm{~B}$ & 11.8 & 4.55 & $4.7 \mathrm{~B}$ \\
AGA & $25.4 \mathrm{~A}$ & 15.3 & $3.6 \mathrm{~B}$ & $6.3 \mathrm{~A}$ \\
SASA-5 & $32.4 \mathrm{~A}$ & 12.9 & $6.7 \mathrm{~B}$ & $4.4 \mathrm{~B}$ \\
LSD & 12.7 & NS & $14.9 \mathrm{~A}$ & 1.2 \\
\hline
\end{tabular}

NS = non-significant; The means not sharing a letter in common in each row (for either the Weed conditions, or Maize cultivars) differ significantly at $\mathrm{p}=0.05$ according to least significant difference (LSD) test; ${ }^{2}$ The figures in the parenthesis show the percent decrease in the plant parameters due to competition with barnyardgrass.

Table 5. Effect of different forage maize cultivars on fresh and dry weights of barnyardgrass

\begin{tabular}{l|cccc}
\hline & \multicolumn{2}{|c}{ Weed fresh weight $(\mathrm{g})$} & \multicolumn{2}{c}{ Weed dry weight $(\mathrm{g})$} \\
\hline Cultivars & Spring & Summer & Spring & Summer \\
ADA-523 & 2.2 & $2.7 \mathrm{~b}^{1}$ & 0.57 & 1.3 \\
AGA & 2.3 & $6.7 \mathrm{a}$ & 0.68 & 1.8 \\
SASA-5 & 1.7 & $5.9 \mathrm{a}$ & 0.45 & 1.4 \\
LSD & NS & 2.59 & NS & NS \\
\hline
\end{tabular}

NS = non-significant; ${ }^{1}$ The means not sharing a letter in common in each row differ significantly at $\mathrm{P}=0.05$ according to least significant difference (LSD) test.

\section{Discussion}

The study demonstrated a serious negative impact of barnyardgrass competition on growth of forage maize cultivars. A significant decrease in the growth parameters (fresh weight and biomass of maize plants, plant height, leaf length and width, number of leaves, root fresh weight and biomass) of the cultivars was noted as a result of weedcrop competition. The germination, seedling emergence and seedling development of barnyardgrass and maize plants coincided in this study, and this damaged the maize plants. If the germination time of weeds and maize plants is close to each other, weeds can cause a greater damage to crop plants than the later germination or emergence of the weeds (Bosnic and Swanton, 1997). This has been previously observed for the competitions of Palmer amaranth (Amaranthus palmeri S.Watson)-maize, barnyardgrass-maize, and Giant ragweed (Ambrosia trifida L.)-maize (Bosnic and Swanton, 1997; Harrison et al., 2001; Travlos et al., 2011). Previous studies too have reported the losses caused to maize crop by weed competition. For example, Doğan et al. (2004) reported that full-season weedy treatment could have a nearly $40 \%$ lower yield than the weed-free treatment. Barnyardgrass has been found to cause damages to other crops as well. For example, Wang et al. (2019) reported that barnyardgrass could reduce the rate of photosynthesis, Rubisco activity, energy conversion efficiency and grain yield in rice. Similarly, the weed decreased the fertile tillers and grains per panicle in rice (Aminpanah, 2012).

Cultivars did not vary for their weed-competitive ability i.e., interaction of weedy conditions $\times$ forage maize cultivars was found non-significant in this study. The traits that impart a weed competitive ability to crop cultivars are speedy germination, fast growth rate, large leaf area, and high height (Sardana et al., 2017). The crop cultivars that possess greater of these characteristics are likely to be greater competitors against weeds. In this study too, there were some differences observed in the growth behavior of the three cultivars in the study. For instance, maize cultivar ADA-523 had a greater plant height, leaf width, leaf length, leaf fresh weight and leaf dry weight than the other two cultivars in the study. However, this growth advantage of the ADA-523 could not be channelized into its weed suppressive ability except a reduction in the weed fresh weight in the spring season study. Other cultivars too gained some growth advantages such as SASA-5 had produced the highest shoot fresh and dry weight (only in spring season) and, SASA-5 and AGA cultivars had an advantage in root biomass production over the ADA-523 cultivar. Nevertheless, these growth advantages of the maize cultivars could not be translated into their weed-competitive ability. This research work concludes that barnyardgrass had significantly decreased the growth and dry biomass production of maize cultivars. However, maize cultivars expressed only minor suppression of the barnyardgrass.

\section{References}

Aminpanah H. 2012. Response of more and less competitive rice cultivars to different densities of barnyardgrass. Electro. J. Crop Prod., 4: 67-84.

Bajwa AA, Jabran K, Shahid M, Ali HH, Chauhan BS. 2015. Ecobiology and management of Echinochloa crus-galli. Crop Prot., 75: 151-162.

Bosnic AC, Swanton CJ. 1997. Influence of barnyardgrass (Echinochloa crus-galli) time of emergence and density on corn (Zea mays). Weed Sci. 45: 276-282.

Crowder DW, Northfield TD, Strand MR, Snyder, WE. 2010. Organic agriculture promotes evenness and natural pest control. Nature, 466: 109-112.

Doğan MN, Ünay A, Boz Ö, Albay F. 2004. Determination of optimum weed control timing in maize (Zea mays L.). Turk. J. Agric. For., 28: 349-354. 
FAO. 2016. FAOSTAT. Food and Agriculture Organization of the United Nations. Available online: http://www.fao.org/faostat/en/\#data/QC/visualize. Accessed 12.08.2018.

Farooq M, Jabran K, Cheema ZA, Wahid A, Siddique KHM. 2011. The role of allelopathy in agricultural pest management. Pest Manag. Sci., 67: 493-506.

Heap I. 2014. Global perspective of herbicide-resistant weeds. Pest Manag. Sci., 70: 1306-1315.

Jabran K, Ata Z., Farooq M. 2007. Maize: cereal with a variety of uses. DAWN-Business. Available online: https://www.dawn.com/news/236949. Accessed: 12.08.2018.

Jabran K, Chauhan BS. 2018a. Non-Chemical Weed Control. 1st ed.; Sciencedirect, Academic Press, USA.

Jabran K, Chauhan BS. 2018b. Overview and significance of nonchemical weed control. In Non-Chemical Weed Control, 1st ed.; Jabran K, Chauhan BS. Eds.; Sciencedirect, Academic Press, USA, 2018, pp. 1-8.

Jabran K, Hussain M, Chauhan BS. 2017. Integrated weed management in maize cultivation: an overview. In: Watson D. (ed.). Achieving Sustainable Cultivation of Maize. Burleigh Dodds Science Publishing Limited. Cambridge UK. http://dx.doi.org/10.19103/AS.2016.0002.21.

Jabran K, Mahajan G, Sardana V, Chauhan BS. 2015. Allelopathy for weed control in agricultural systems. Crop Prot., 72: 57 65.
Jabran K. 2017a. Manipulation of Allelopathic Crops for Weed Control. $1^{\text {st }}$ ed.; Springer Nature International Publishing, Switzerland AG.

Jabran K. 2017b. Wheat allelopathy for weed control. In: K. Jabran, Manipulation of Allelopathic Crops for Weed Control. SpringerBriefs in Plant Science, Springer International Publishing AG, Switzerland. pp. 13-20

Massinga RA, Currie RS, Horak MJ, Boyer J. 2001. Interference of Palmer amaranth in corn. Weed Sci., 49: 202-208.

Oerke EC. 2006. Crop losses to pests. J. Agric. Sci., 144: 31-43.

Reganold JP, Wachter JM. 2016. Organic agriculture in the twenty-first century. Nature Plants, 2: 15221.

Sardana V, Mahajan G, Jabran K, Chauhan BS. 2017. Role of competition in managing weeds: An introduction to the special issue. Crop Prot., 95: 1-7.

Shiferaw B, Prasanna BM, Hellin J, Bänziger M. 2011. Crops that feed the world 6. Past successes and future challenges to the role played by maize in global food security. Food Secur., 3: 307-327.

Travlos IS, Economou G, Kanatas PJ. 2011. Corn and barnyardgrass competition as influenced by relative time of weed emergence and corn hybrid. Agron. J., 103: 1-6.

Wang XL, Zhang ZY, Xu XM, Li G. 2019. The density of barnyard grass affects photosynthesis and physiological characteristics of rice. Photosynthetica, 57: 705-711. 